BASEMENT FLOODING AND FOUNDATION DAMAGE FROM WATER-TABLE RISE

IN THE EAST NEW YORK SECTION OF BROOKLYN, LONG ISLAND, NEW YORK

By Julian Soren

U.S. GEOLOGICAL SURVEY

Water-Resources Investigations 76-95

Prepared in cooperation with the

New York State Department of Environmental Conservation 


\section{UNITED STATES DEPARTMENT OF THE INTERIOR \\ Thomas S. Kleppe, Secretary \\ GEOLOGICAL SURVEY \\ V. E. Mckelvey, Director}

For additional information write to:

U.S. Geological Survey

1505 Kellum Place

Mineola, New York 11501 
Conversion factors and abbreviations.................. iv

Abstract.................................. I

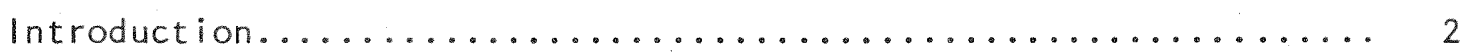

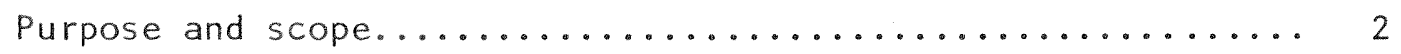

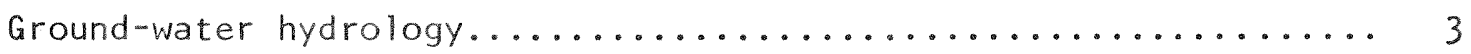

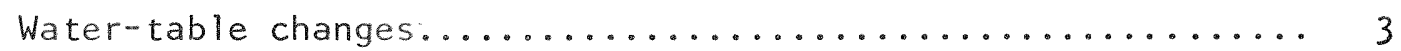

Engineering considerations..................... 4

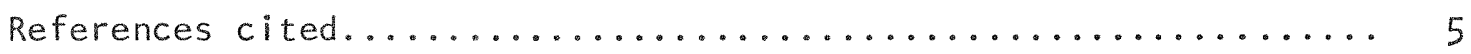

\section{ILLUSTRATIONS}

Figure 1. Map of Long Island, N.Y., showing location of East New York and vicinity, Kings County, N.Y..... 6

2-7. Maps of the water table in East New York and vicinity, Kings County, N.Y., from 1903 to 1976:

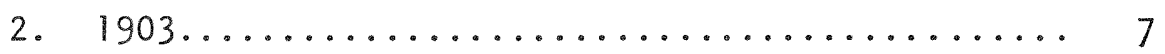

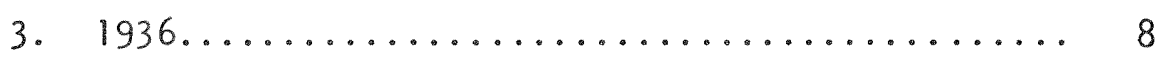

4. December 1950....................... 9

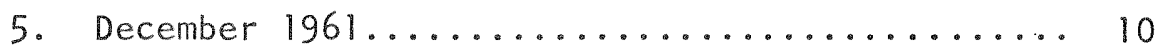

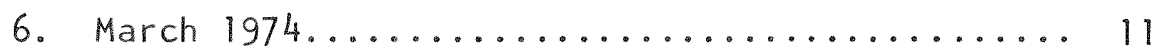

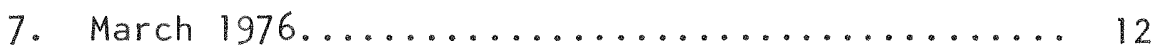

8. Hydrographs showing average water-table altitudes at observation wells in East New York and Brownsville, Kings County, N.Y., from 1933 to $1976 \ldots . . . . . .13$

9. Approximate depths to water table in East New York and vicinity, Kings County, N.Y., in March 1976... 14 


\section{CONVERSION FACTORS AND ABBREVIATIONS}

$\begin{array}{lcl}\text { Multiply English units } & \text { by } & \text { To obtain Sl units } \\ \begin{array}{l}\text { feet }(\mathrm{ft}) \\ \begin{array}{l}\text { million gallons per day } \\ (\text { Mgal/d) }\end{array}\end{array} & 0.3048 & \text { metres }(\mathrm{m}) \\ \text { miles }(\mathrm{mi}) & 1.609 & \begin{array}{c}\text { cubic metres per second } \\ (\mathrm{m} 3 / \mathrm{s})\end{array} \\ \text { square miles }\left(\mathrm{mi}^{2}\right) & 2.590 & \text { kilometres }(\mathrm{km})\end{array}$




\title{
BASEMENT FLOODING AND FOUNDATION DAMAGE FROM WATER-TABLE RISE IN THE EAST NEW YORK SECTION OF BROOKLYN, LONG ISLAND, NEW YORK
}

\section{By}

\author{
Julian Soren
}

\section{ABSTRACT}

A rising water table has been causing basement flooding and damage to building foundations in the East New York section of Brooklyn, Kings County, Long |sland, N.Y., since the early fall of 1975.

The rising water table is the result of shutdown of public-supply wells that had pumped large amounts of water from the early 1900's to 1974. The pumping was stopped to halt the intrusion of sea water into the ground-water reservoir. The water table in East New York and vicinity declined from an unknown altitude before the pumping began, which probably ranged from more than 10 to 15 feet ( 3 to 4.6 metres) above mean sea level in the central part of the area, to as deep as 12 feet ( 3.7 metres) below sea level in 1936. Water-table recovery followed cessations of pumping in 1947 and 1974, and, by 1976, the water table had risen as high as 8 to 10 feet $(2.4$ to 3 metres) above sea level, causing the flooding. If the present recovery rate continues, the water table is expected to rise another 2 to 4 feet $(0.6$ to 1.2 metres) in the next several years.

Relief of the basement-flooding problem in East New York and vicinity is complicated by the fact that the New York City sewer system carries both untreated sewage and storm-water runoff into sewage-treatment plants that cannot process all the inflow during times of heavy precipitation. Pumped ground water discharged into sewers could, therefore, adversely affect operations at treatment plants. Other suggested remedial measures, such as onsite injection of pumped ground water into deep confined aquifers or discharging it through separate pipelines to tidewater, are complicated by the poor quality of the pumped water and by the sea-water intrusion that would be caused by prolonged pumping. 


\section{INTRODUCTION}

A rising water table in the East New York section of Brooklyn, Kings County, N.Y., is causing damage to building foundations and flooding basements. The affected area, about $16 \mathrm{mi}^{2}\left(41 \mathrm{~km}^{2}\right)$, is a densely populated part of New York City at the west end of Long Island (fig. 1).

In the early fall of 1975, the U.S. Geological Survey, Mineola, N.Y., began to receive complaints and inquiries from public officials and consulting engineers about ground water seeping into deep basements of large institutional buildings such as public schools and a hospital in East New York and vicinity. The ground-water seepage is reportedly causing cracks to develop in concrete foundations, probably through hydrostatic pressure and differential settling, and is also causing damage to equipment and materials stored in the basements. An article in "The New York Times," March 28, 1976, p. 2BK, reported that seven schools, a hospital, and a store had been affected by basement flooding.

\section{Purpose and Scope}

The purpose and scope of this report is to present the factors that have caused the water-table rise in the East New York section of Brooklyn. The rising water table in kings County is not sudden or new; it has a history of more than two decades. This report will refocus attention on the problem of changing ground-water levels in areas where intensive ground-water pumping has ceased or is occurring.

Reports dealing with rising ground-water levels in Kings County were made by Lusczynski (1952) and PerImutter and Soren (1963). A report on adjacent Queens County by Soren (1971) describes potential problems from water-table rise should current intensive pumping in this county cease. 


\section{GROUND-WATER HYDROLOGY}

The rising water table has been caused mainly by the cessation of pumping. The rise began in 1947, when public-supply ground-water pumping by a private water company in nearby Flatbush, Kings County, was stopped by the City of New York because it was causing sea-water intrusion and deterioration of water quality (Lusczynski, 1952, p. 1, 5, 6). The center of pumping was about $4 \mathrm{mi}(6.4 \mathrm{~km})$ west-southwest of East New York. The water company had been pumping since 1904, and pumpage had increased from $4 \mathrm{Mgal} / \mathrm{d}\left(0.18 \mathrm{~m}^{3} / \mathrm{s}\right)$ in 1904 to $25 \mathrm{Mgal} / \mathrm{d}(1.1 \mathrm{~m} / \mathrm{s})$ during 1930-46. Pumpage was reduced to about half in 1946 and was continued at the reduced rate until the wells were shut down in June 1947 . The water-table rise was accelerated in 1972 when a private water company that had been pumping $10 \mathrm{Mgal} / \mathrm{d}\left(0.4 \mathrm{~m}^{3} / \mathrm{s}\right)$ since the mid-1950's in the adjacent Woodhaven section of Queens County, N.Y., reduced pumpage to $1.4 \mathrm{Mgal} / \mathrm{d}\left(0.06 \mathrm{~m}^{3} / \mathrm{s}\right)$. This company ceased pumping entirely at the end of 1974--also because of deteriorated water quality from sea-water intrusion (R. J. O'Reilly, New York State Department of Environmental Conservation, oral commun., April 13, 1976). The Woodhaven pumping center was about $2 \mathrm{mi}(3.2 \mathrm{~km})$ east-northeast of central East New York.

\section{Water-Table Changes}

The earliest known map of the water table on Long Island shows the water-table altitude in East New York and vicinity in 1903 (fig. 2). In 1903, the water table in the central part of the report area was 10 to $15 \mathrm{ft}(3$ to $4.6 \mathrm{~m})$ above sea level. The original height of the water table is not known because, even at that time, pumpage for water supply by the City of New York and by a private water company was $2.5 \mathrm{Mgal} / \mathrm{d}$, or $0.1 \mathrm{~m} 3 / \mathrm{s}$ (Veatch and others, 1906, p. 189, well nos. 134 and 135). other pumping, although not recorded, probably existed also. This pumping undoubtedly accounted, in part, for the apparent drawdown indicated by the contour lines in figure 2.

A map of the water table in Kings county for 1936 shows it to be 5 to $10 \mathrm{ft}(1.5$ to $3 \mathrm{~m})$ below sea level in the central part of the East New York vicinity and ranging from 12 to $3 \mathrm{ft}(3.7$ to $1 \mathrm{~m})$ below sea level from west to east (fig. 3).

The decline of the water table from 1903 to 1936 resulted from the intensive ground-water development in Kings County. The water table in East New York and vicinity remained at about the 1936 levels through 1946.

In 1947, after shutdown of public-supply pumping, the water table in Kings County began to recover. By 1950, it had risen to sea level in the report area (fig. 4) as the large cone of depression in Kings County slowly filled. Between 1950 and 1961, ground water seeped into deep subsurface structures such as basements of large buildings and 
subway tunnels in Kings County, mainly west and northwest of East New York (Perlmutter and Soren, 1963, p. 138). Pumping in Woodhaven retarded the rate of water-table rise in East New York. In 1961, the water table in the central part of the report area was 3 to $5 \mathrm{ft}$ ( 1 to $1.5 \mathrm{~m}$ ) above sea level (fig. 5), but was then still too deep to flood basements. In 1972, public-supply pumpage, which had been about 10 $\mathrm{Mgal} / \mathrm{d}(0.4 \mathrm{~m} / \mathrm{s})$ for more than a decade in Woodhaven, Queens County, was reduced to about $1.4 \mathrm{Mgal} / \mathrm{d}\left(0.06 \mathrm{~m}^{3} / \mathrm{s}\right)$ and to zero by the end of 1974. (Locations of the Woodhaven public-supply wells are shown in fig. 5.) By March 1974, the water table in the central part of East New York and vicinity was 5 to $10 \mathrm{ft}(1.5$ to $3 \mathrm{~m}$ ) above sea level (fig. 6). Complaints of basement flooding began in 1975. By March 1976, the water table had risen to $10 \mathrm{ft}(3 \mathrm{~m})$ above sea level in the central part of East New York (fig. 7).

The ultimate height of water-table recovery in East New York and vicinity is not certain. The earliest known water table (1903) seems to have been already lowered in the central part of the area to about $5 \mathrm{ft}(1.5 \mathrm{~m})$ above sea level (fig. 2). Figure 7 shows a recovering water-table at about $10 \mathrm{ft}(3 \mathrm{~m})$ above sea level in March 1976; the rate of water-table recovery is shown by hydrographs of observation wells in East New York and Brownsville (fig. 8). (Locations of the observation wells are shown in figs. 5 and 7.) Topographic surveys by the U.S. Geological Survey in 1888-89 and 1897 (Brooklyn Quadrangle) show an unnamed stream just east of Rockaway Avenue whose flow began in the northeastern part of Brownsville, $0.25 \mathrm{mi}(0.4 \mathrm{~km})$ south of Sutter Avenue, at an altitude estimated to be between 10 and $20 \mathrm{ft}$ $(3$ and $6 \mathrm{~m}$ ) above sea level. Consequently, it is likely that by 1979 the water table could rise an additional 2 to $4 \mathrm{ft}(0.6$ to $1.2 \mathrm{~m})$ to an altitude of 10 to $12 \mathrm{ft}(3$ to $3.7 \mathrm{~m})$ above sea level in Brownsville and East New York if the present nonpumping conditions and rate of watertable recovery persist. Depths to water table from land surface in March 1976 in East New York and vicinity are shown in figure 9. The ultimate recovery level of the water table will probably be lower than levels in the 1880's because ground-water recharge in the area is now reduced by extensive paving and sewering. Should water levels in the report area approach those of 1903, the water table will range from sea level at the shorel ine to about $20 \mathrm{ft}(6 \mathrm{~m})$ above sea level at the area's northernmost limit (fig. 2). However, because the 1903 water table seems to have already been lowered by pumping, the ultimate recovery level in the area could be higher than the 1903 level.

\section{Engineering Considerations}

Either some of the buildings and other structures in the report area (and other parts of Kings County) were designed on the supposition that the depressed water table would persist, or the builders were unaware that the water table was lowered by intensive pumping. The effects of pumping in Woodhaven, Queens County on the water table in adjacent East New York are 
shown in Soren (1971, plate 2), and comments on the effects of pumping cessation are given in the same report (Soren, 1971, p. 35-36).

Eliminating flooded-basement problems in East New York and vicinity is a complex matter. Dewatering operations that discharge pumped ground water into sewers at affected sites have been considered infeasible by local officials because the New York City sewer system carries both raw wastes and storm runoff, and, at times, storm runoff overloads sewagetreatment facilities, necessitating discharge of untreated sewage to tidewater along with the runoff. An increased discharge into sewers from dewatering operations could, therefore, adversely affect operations at sewage-treatment plants. Other remedial procedures have been considered by local officials, such as installing recharge wells for injecting the pumped shallow ground water into confined deeper aquifers at individual dewatering sites, or installing separate pipelines to discharge the pumped water to nearby tidewater. Arguments against these dewatering-method options are that (1) the quality of pumped shallow ground water in East New York and vicinity may not be suitable for recharge to confined deeper aquifers because the water contains high to excessive amounts of nitrate and considerably greater than natural levels of chloride (Kimmel, 1972, p. 201-202); and (2) prolonged pumping to lower the water table will cause sea-water intrusion and further deterioration of water quality by increasing chloride concentration and hardness.

\section{REFERENCES CITED}

Kimmel, G. E. 1972, Nitrogen content of ground water in Kings County, Long Island, New York: U.S. Geol. Survey Prof. Paper 800-D, p. 199-203.

Koszalka, E. J., 1975, The water table on Long Island, New York, in March 1974: Oakdale, N.Y., Suffolk County Water Authority, Long Island Water Resources Bull. LIWR-5, 7 p., 3 pls.

Lusczynski, N. J., 1952, The recovery of ground-water levels in Brooklyn, New York, from 1947 to 1950: U.S. Geol. Survey Circ. 167,29 p. 2 pls.

Perlmutter, N. M., and Soren, Julian 1963, Effects of major water-table changes in Kings and Queens Counties, New York City: U.S. Geol. Survey Prof. Paper 450-E, p. 136-139.

Soren, Julian, 1971, Ground-water and geohydrologic conditions in Queens County, Long Island, New York: U.S. Geol. Survey WaterSupply Paper 2001-A, 39 p., 2 pls.

Veatch, A. C., Slichter, C. S., Bowman, Isaiah, Crosby, W. 0., and Horton, R. E., 1906, Underground water resources of Long Island, New York: U.S. Geol. Survey Prof. Paper $44,394 \mathrm{p}$. 


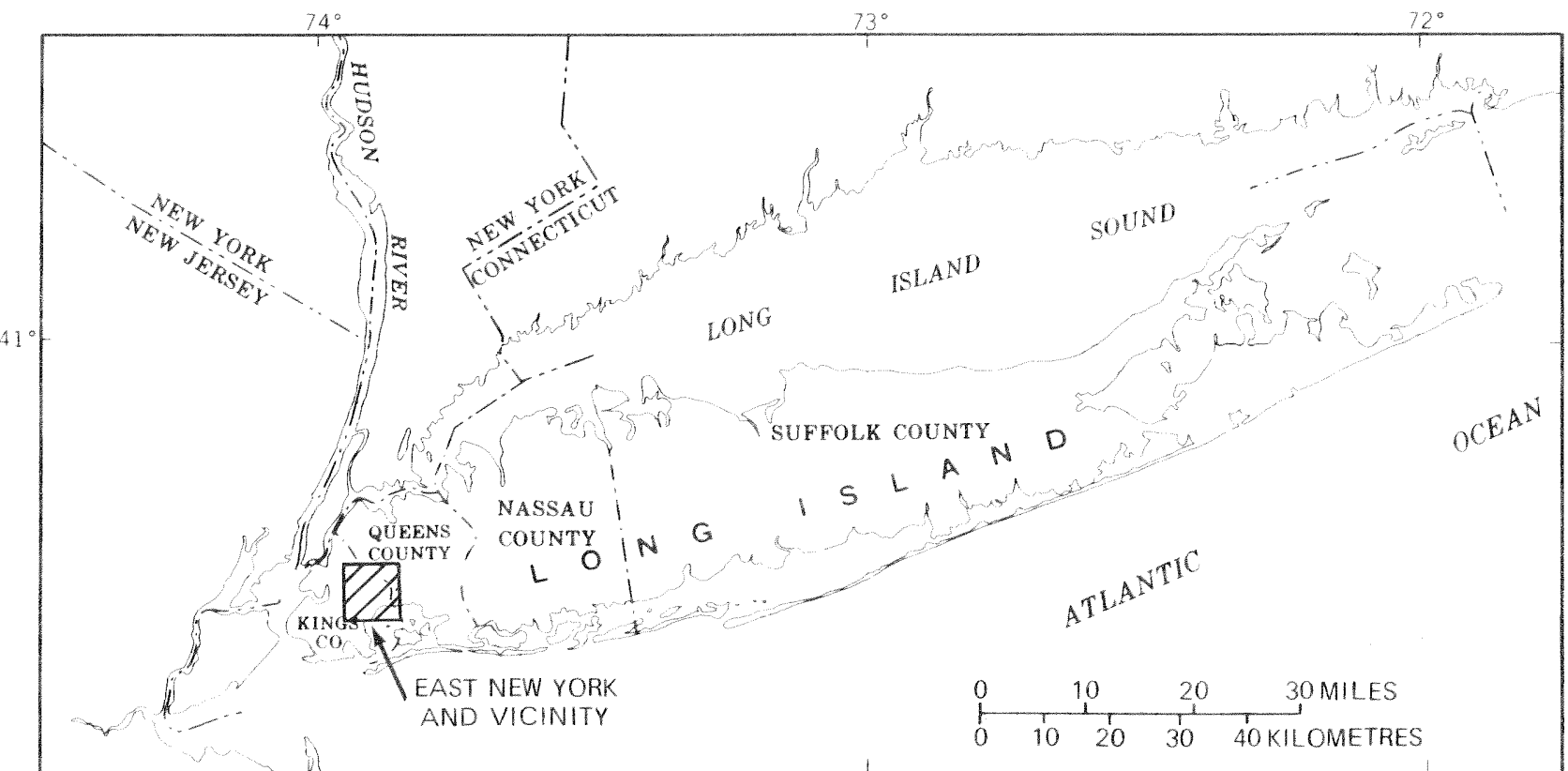

Base from U.S. Geological Survey State base map, 1974

Figure 1.--Map of Long Island, N.Y., showing location of East New York and vicinity, Kings County, N.Y. 


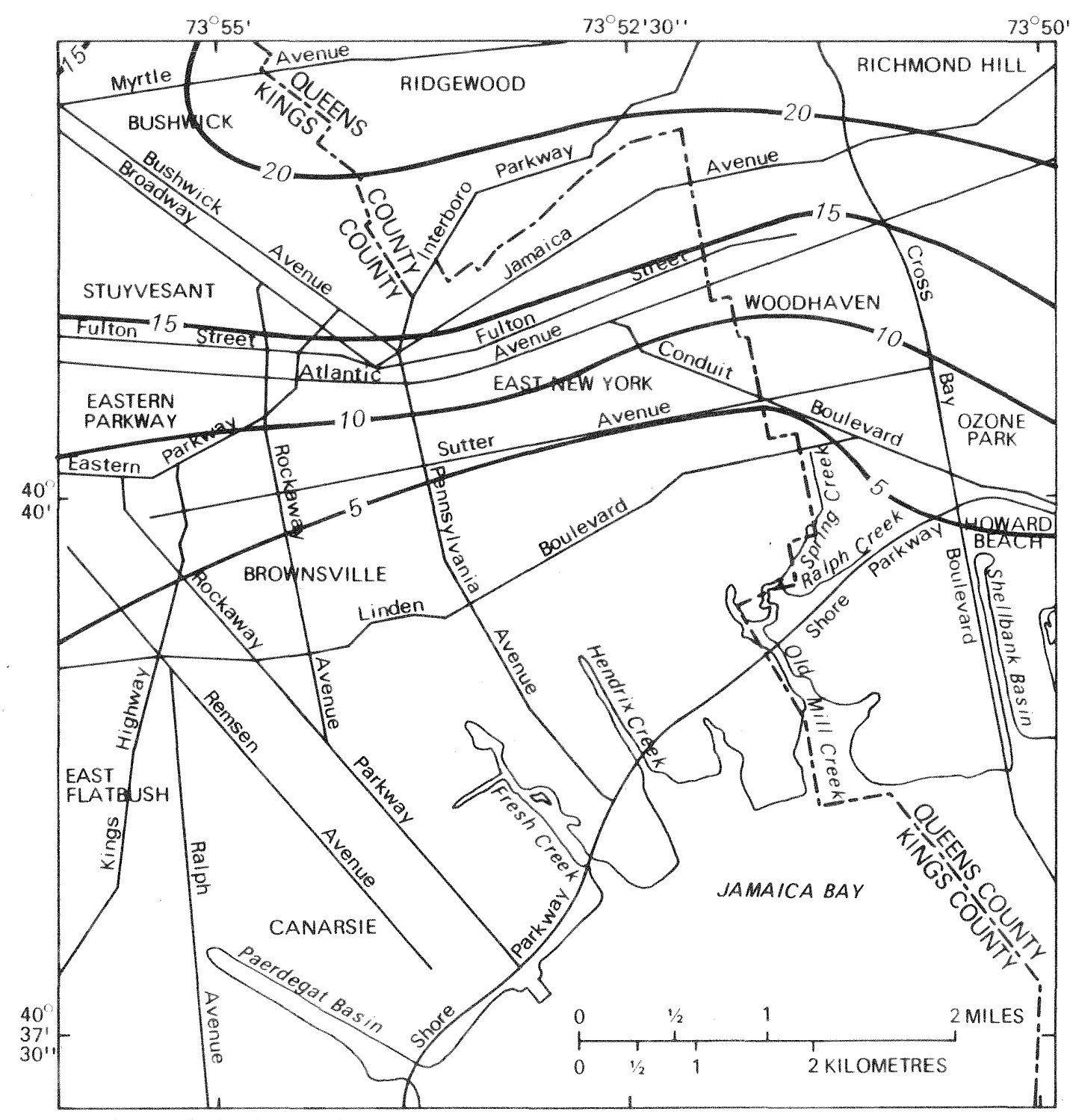

Base from U.S. Geological Survey

Brooklyn. Coney Island, 1967, Jamaica,

1966, and Far Rockaway, 1969, 1:24,000

EXPLANATION

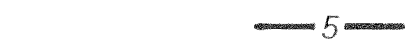

WATER-TABLE CONTOUR -- Shows approximate altitude of water table. Contour interval 5 feet. Datum is mean sea level

Figure 2.- -Water table in East New York and vicinity, Kings County, N.Y., in 1903 (from Lusczynski, 1952). 


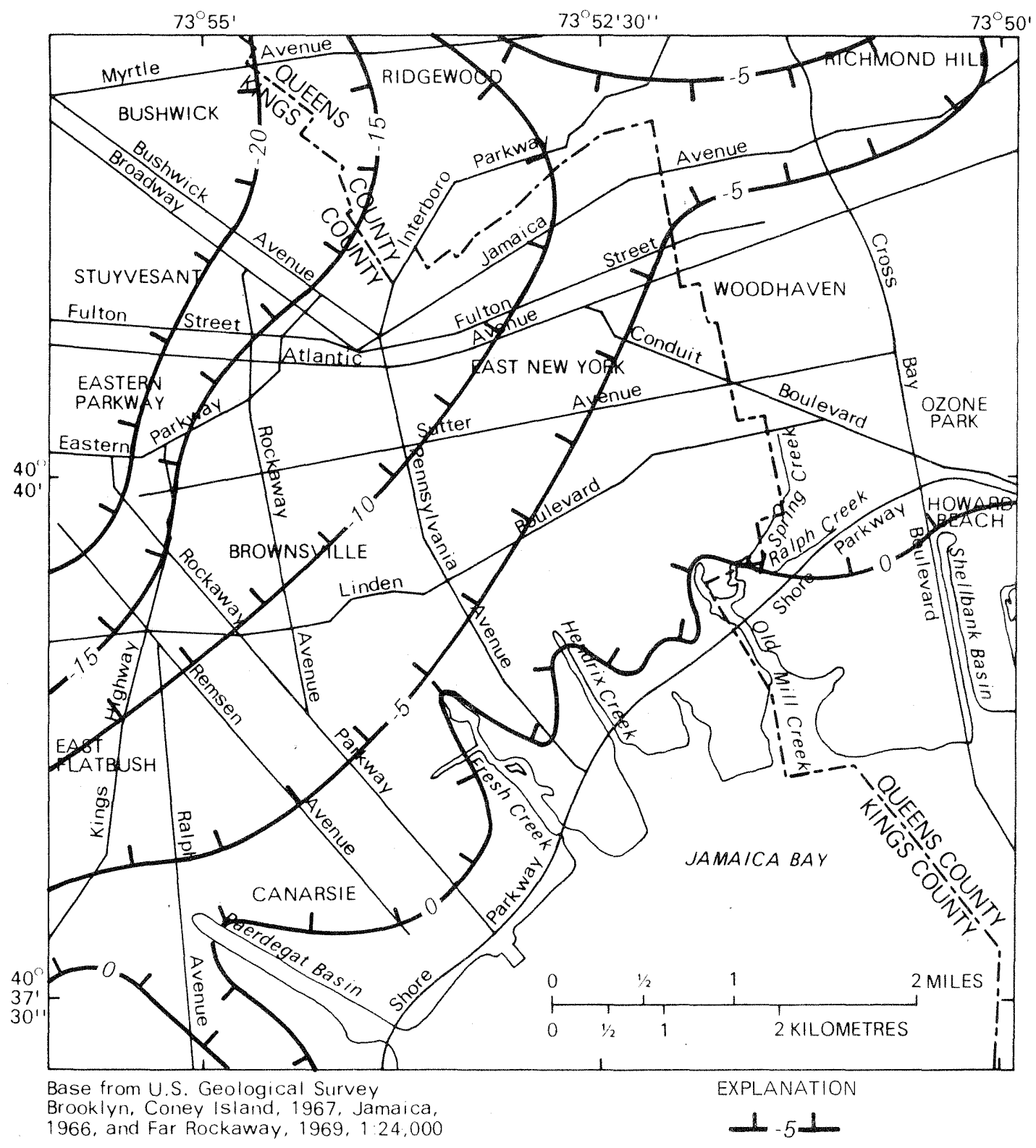

WATER-TABLE CONTOUR -- Shows approximate altitude of water table. Hachures indicate depression. Contour interval 5 feet. Datum is mean sea level

Figure 3.--Water table in East New York and vicinity, Kings County, N.Y., in 1936 (from Lusczynski, 1952). 


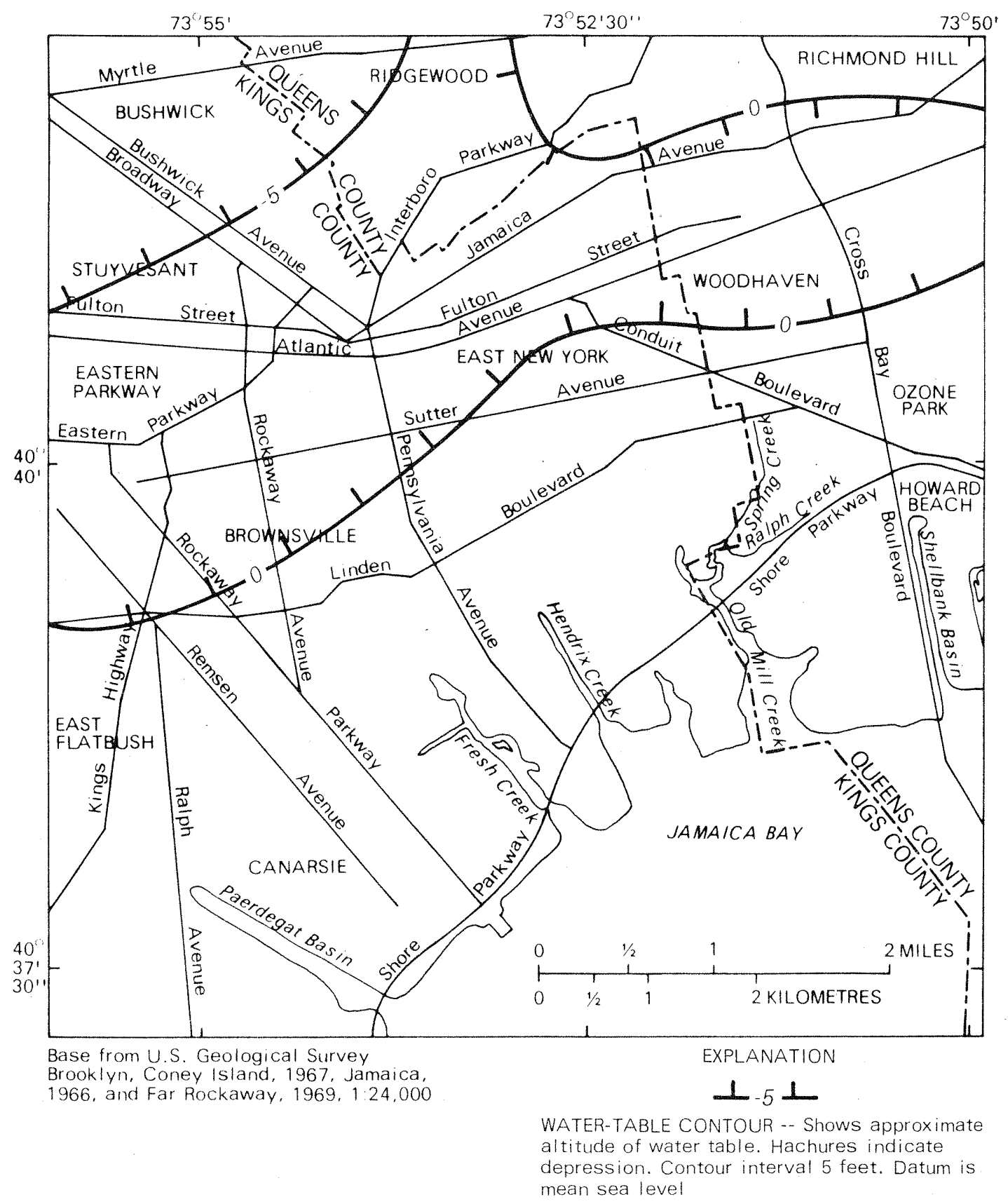

Figure 4.--Water table in East New York and vicinity, Kings County, N.Y., in December 1950 (from Lusczynski, 1952). 


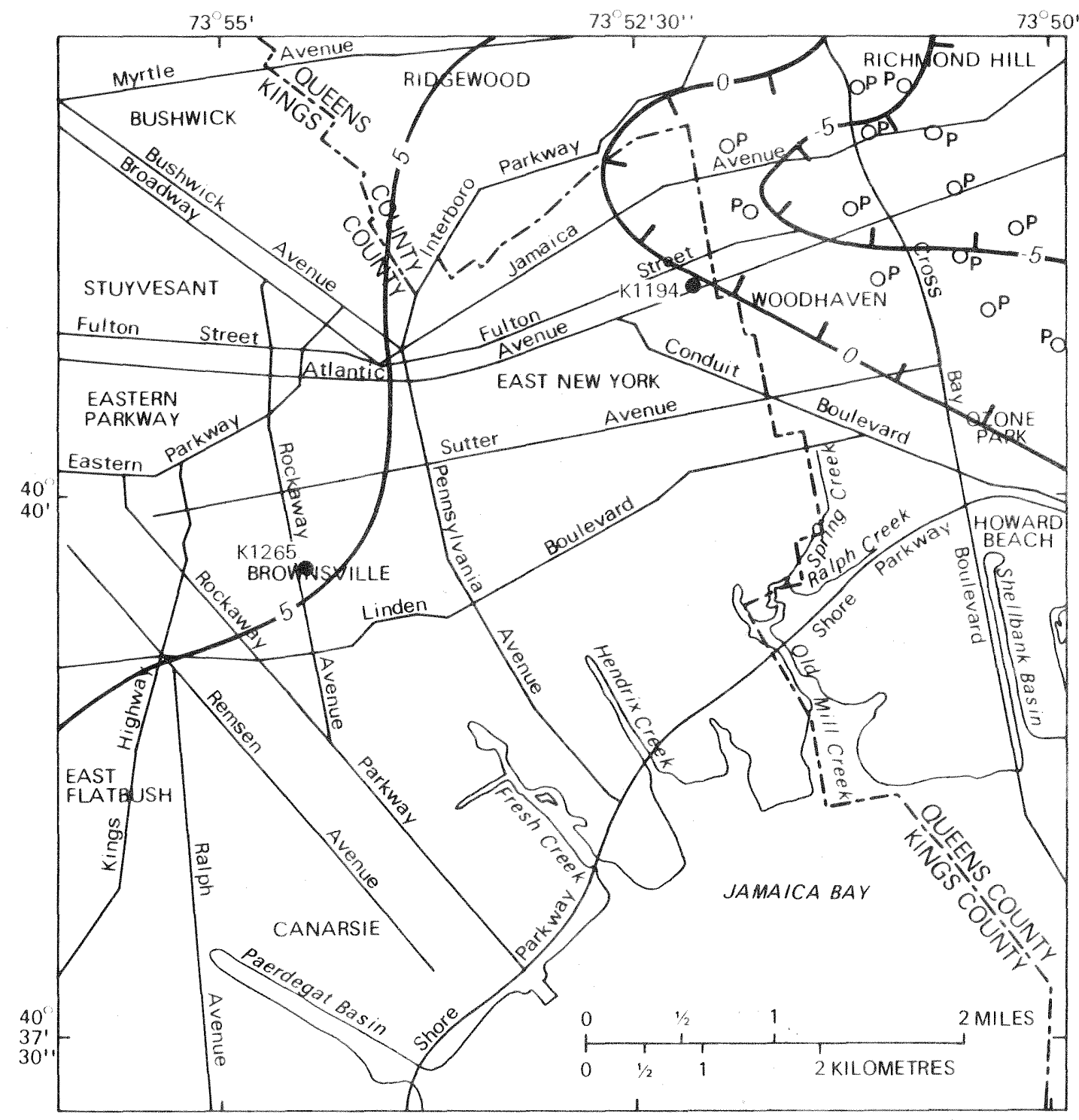

Base from U.S. Geological Survey

Brooklyn. Coney Island, 1967, Jamaica,

1966, and Far Rockaway, 1969, 1:24,000

Hydrology by Julian Soren, 1976

EXPLANATION

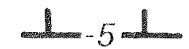

WATER-TABLE CONTOUR -- Shows approximate altitude of water table. Hachures indicate depression. Contour interval 5 feet. Datum is mean sea level

K1265

OBSERVATION WELL

$\mathrm{OP}$

ACTIVE PUBLIC-SUPPLY WELL

Figure 5.--Water table in East New York and vicinity, Kings County, N.Y., in December 1961 (adapted in part from Soren, 1971). 


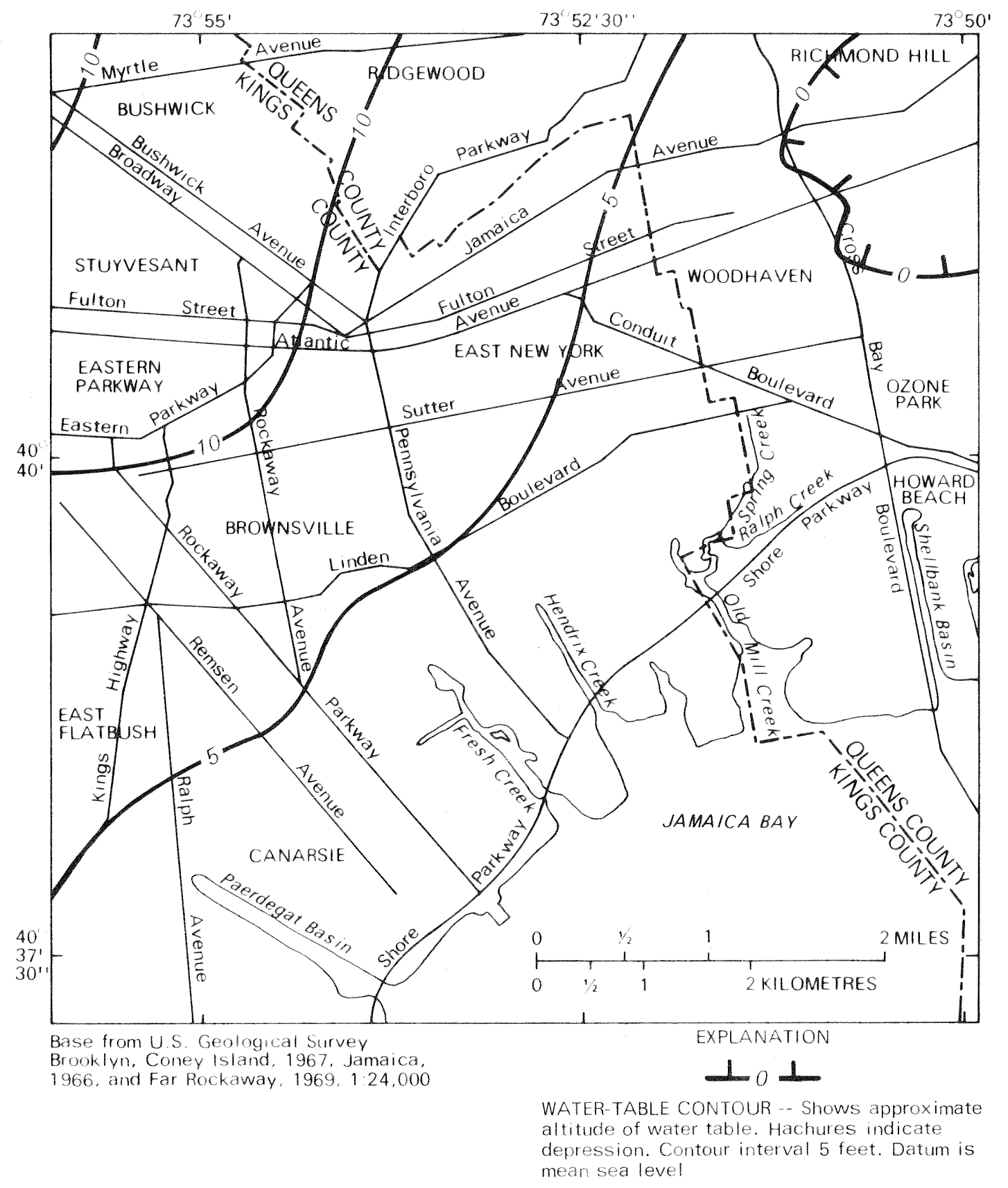

Figure 6.--Water table in East New York and vicinity, Kings County, N.Y., in March 1974 (from Koszalka, 1975). 


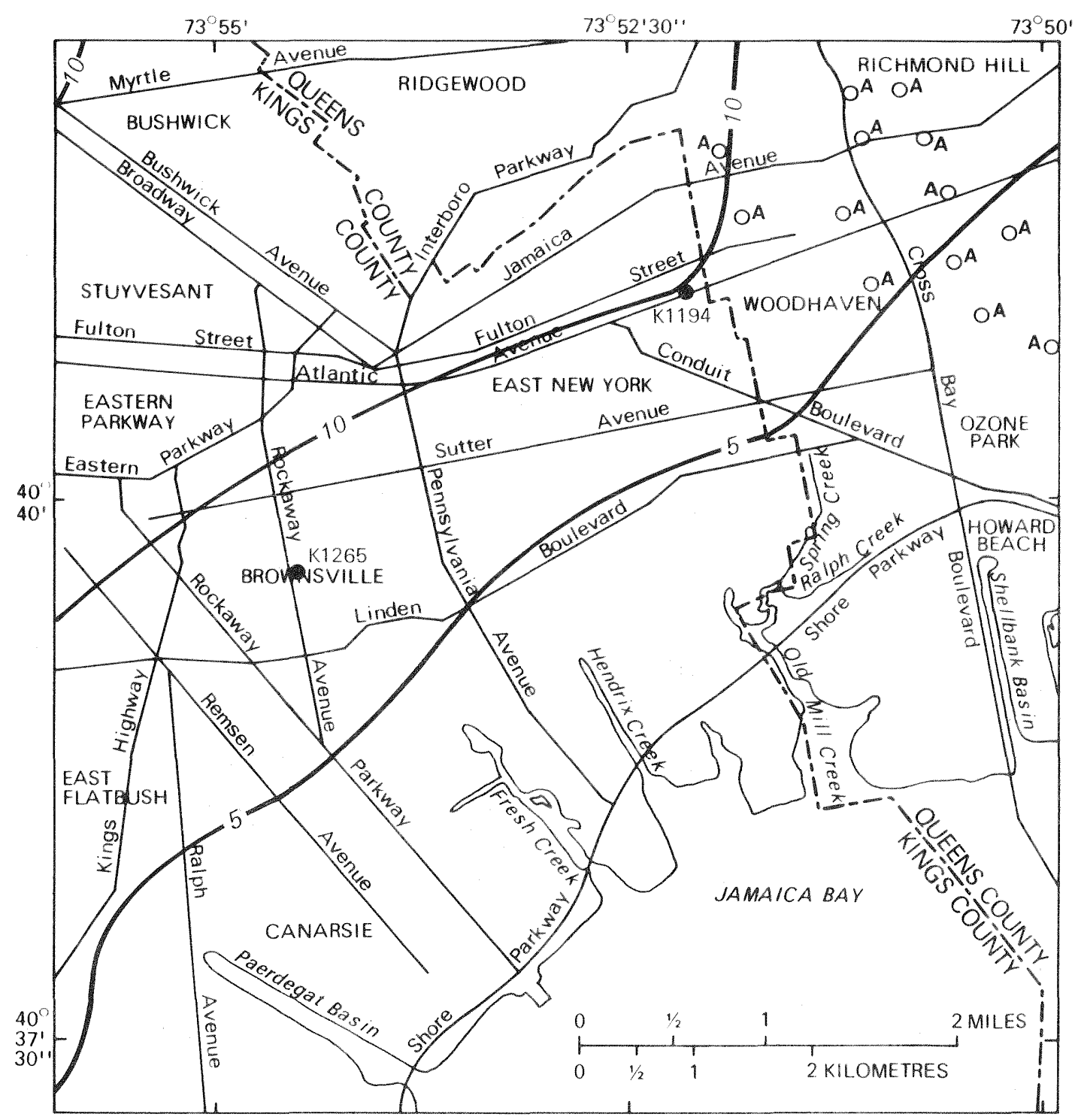

Base from U.S. Geological Survey Brooklyn. Coney Island, 1967. Jamaica, 1966. and Far Rockaway, 1969, 1:24.000

Hydrology by Julian Soren, 1976 EXPLANATION WATER-TABLE CONTOUR -.- Shows approximate
altitude of water table. Contour interval 5 feet.
Datum is mean sea level

$$
\begin{gathered}
\text { K1265 } \\
\text { OBSERVATION WELL } \\
\text { OA } \\
\text { ABANDONED PUBLIC-SUPPLY WELL }
\end{gathered}
$$

Figure 7.--Water table in East New York and vicinity, Kings County, N.Y., in March 1976. 


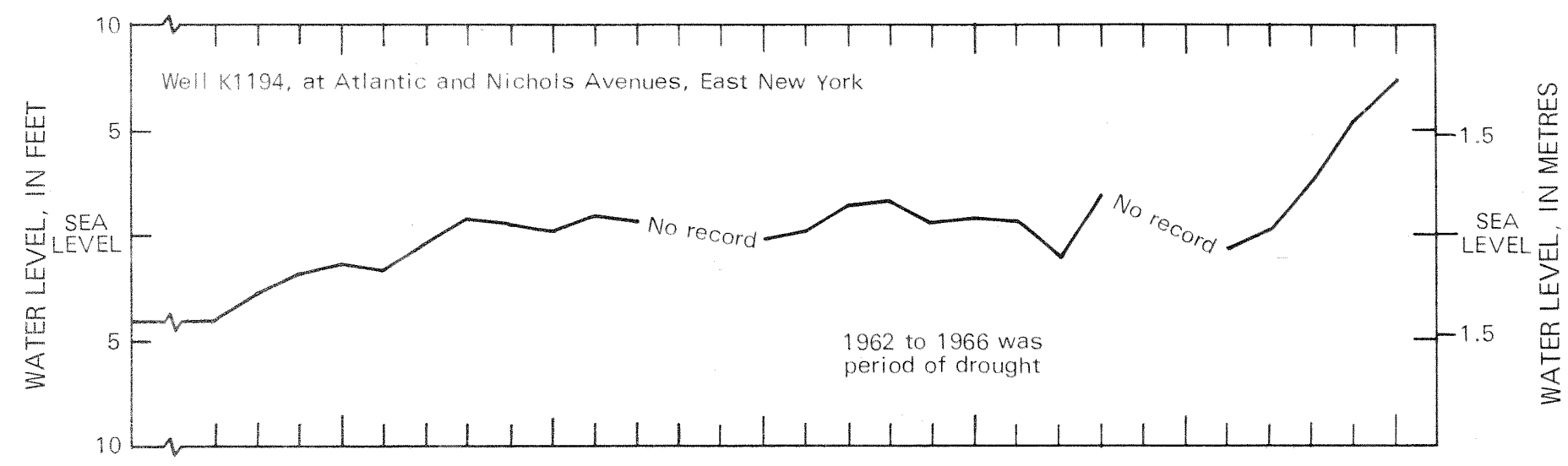

$\bar{\omega}$

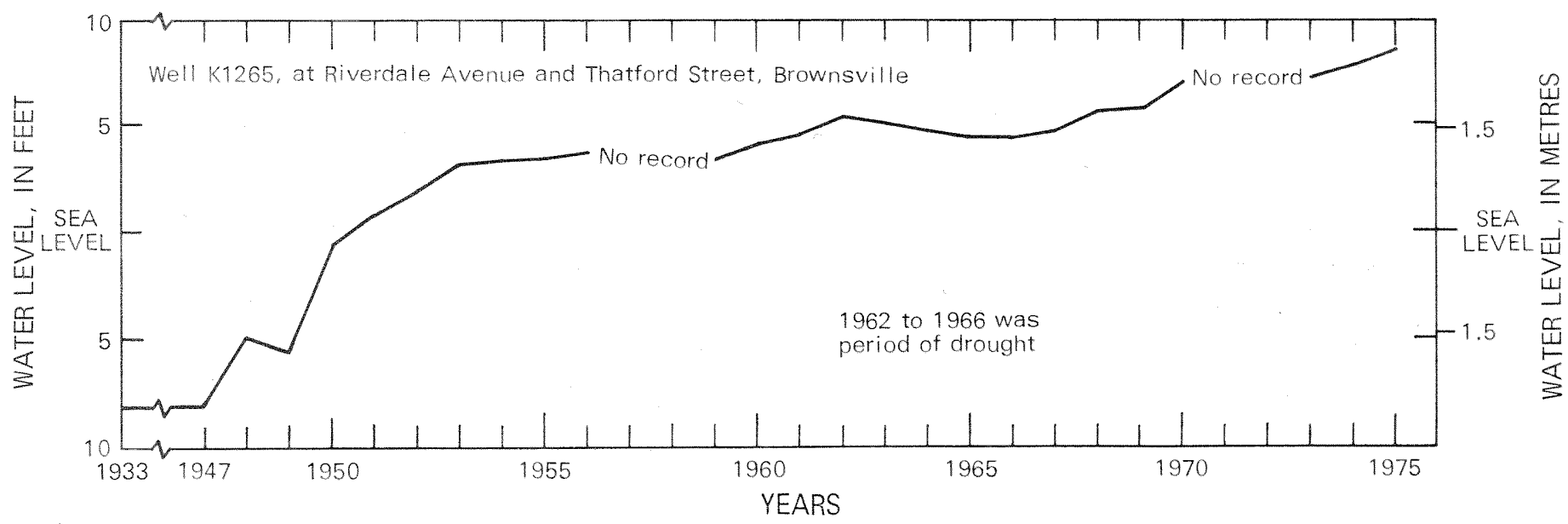

Figure 8.--Average water-table altitudes at observation wells in East New York and Brownsville, Kings County, N.Y., from 1933 to 1976. 


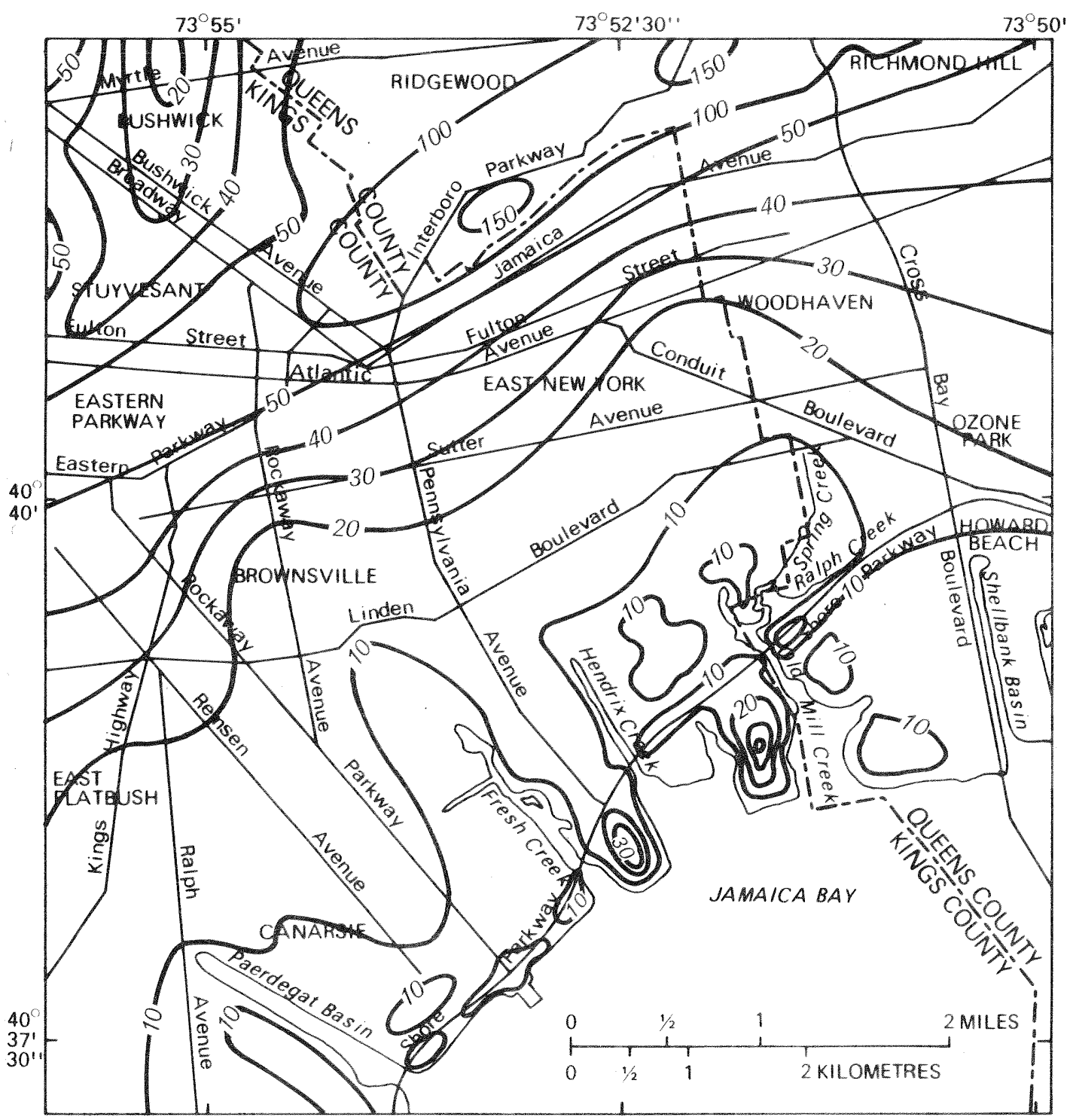

Base from U.S. Geological Survey

Brooklyn, Coney island, 1967. Jamaica,

1966, and Far Rockaway, 1969, 124,000

Hydrology by Julian Soren, 1976 EXPLANATION

$-10-$

LINE OF EOUAL DEPTH TO WATER. Interval 10 and 50 feet. Datum is land surface

Figure 9.--Approximate depths to water table in East New York and vicinity, Kings County, N.Y. in March 1976. 